\title{
Treatment of high-salt oil produced water based on constructed wetland technology-A case study of a costal oilfield
}

\author{
Xiaoqing $\mathrm{Cao}^{1}$, Xue $\mathrm{Gao}^{1}$, Kai Zheng ${ }^{1}$, Shan Wu${ }^{1}$, Guodong Meng ${ }^{1}$, Xiaohui Xie ${ }^{1}$, and Jixin $\mathrm{Su}^{1, *}$ \\ ${ }^{1}$ School of Environmental Science and Engineering, Shandong University, China
}

\begin{abstract}
Aiming at the treatment of large volume of oil produced wastewater, the combined technology based on constructed wetland was applied for produced water treatment in a costal oil field. During the stable operation period, the treatment system maintained removal efficiency of $50.2 \%$ for chemical oxygen demand (COD), $100 \%$ for oil and $85.1 \%$ for ammonium nitrogen (NH3-N) under the gradient increase of salinity along the process. Meanwhile, this system has a good ability to adapt the influent fluctuation. When the oil in the influent fluctuated greatly between $11 \mathrm{mg} / \mathrm{L}$ to $147 \mathrm{mg} / \mathrm{L}$, the effluent water quality remained stable. The treated water met the national discharge standard for water pollutants from the oilfield industry and can be used for the saline alkali beach wetland as supplement water.
\end{abstract}

\section{Introduction}

A large volume of wastewater will be produced in the process of oil exploitation, with the characteristics of high temperature and salinity[1]. Most of the oilfields in China have now entered into the third oil recovery stage, where produced wastewater is even more than 10 times of oil production[2]. The oilfield produced water contains not only large amounts of hydrocarbons, which are easy to be biodegraded, but also a high proportion of complex organic compounds, such as PAHs and benzene series[3]. These refractory substances generally have high toxicity and pathogenicity, which will cause huge pollution to the environment and threat to human health[4]. Thus, these wastewaters must be properly treated before discharge into the environment.

Treatment methods of oil produced wastewater mainly focus on physiochemical methods and biological methods[5]. Compared to the physical and chemical process, the biological treatment is more economical and environment-friendly. However, due to the high COD and complex composition of produced water, it is difficult to achieve the desired effect by using a single treatment method[6]. At present, the physicochemical method is generally used to pre-treat the produced wastewater first, and then subject it to the advanced biological treatment processes[7].

Constructed wetlands have been wildly used in combination with other processes to treat oilfield produced water[8][9]. Research on constructed wetland began in 1953 with Dr. Kat he Seidel. In 1974, the first complete constructed wetland was built in liebenburg othfresen, Germany[10]. In this basis, the related research was exploded both at home and overseas. Now constructed wetland technology has been widely used in oil produced wastewater treatment around the world. It was considered that the purification of wastewater in wetland was a synergistic effect of substrate, plant and microorganism[11]. The substrate can remove part of the pollutants through adsorption, ion exchange and other ways. Meanwhile, it has large specific surface aera, which provides sufficient adhesion interface for microorganisms[12]. Plants can remove pollutants through adsorption and assimilation during the growth, and affects the structure of rhizosphere microbial community by build the rhizosphere microenvironment[10]. Besides, Microorganisms remove pollutants from water through various physiological metabolic pathways[13][14].

In this study, we investigated the operational performance of a combined system based on constructed wetland from a costal oilfield. The purification efficiency was analysed through monitoring water quality to demonstrate the feasibility of this process for produced wastewater treatment, in order to achieve the recycling of water resources and achieve the goal of zero discharge of oilfield wastewater.

\section{Process background and methods}

\subsection{Characteristics of produced water}

The oil produced wastewater in this study was from a costal Oilfield with daliy discharge of oil produced wastewater about $3000 \mathrm{~m}^{3}$. The oilfiled wastewater was characterized by high temperature, high salinity, complex organic composition and low biodagradable. The main physical and chemical properties of the produced water were listed in Table 1.

\footnotetext{
* Corresponding author: jxsu@sdu.edu.cn
} 
Table1. Characteristics of the raw OPW.

\begin{tabular}{ccc}
\hline Parameter & Range & Average \\
\hline $\mathrm{pH}$ & $7.08-7.28$ & 7.19 \\
$\mathrm{COD}$ & $263-375$ & 358 \\
$\mathrm{BOD} 5(\mathrm{mg} / \mathrm{L})$ & $92.7-114$ & 103.2 \\
$\mathrm{NH}_{3}-\mathrm{N}(\mathrm{mg} / \mathrm{L})$ & $18.5-22.7$ & 20.3 \\
$\mathrm{SS}(\mathrm{mg} / \mathrm{L})$ & $53-64$ & 57 \\
Oil $(\mathrm{mg} / \mathrm{L})$ & $105-127$ & 115 \\
Total nitrogen $(\mathrm{mg} / \mathrm{L})$ & $97.6-110$ & 103.7 \\
Volatile phenols & $0.027-0.038$ & 0.033 \\
$(\mathrm{mg} / \mathrm{L})$ & $0.064-0.080$ & 0.072 \\
Sulphides $(\mathrm{mg} / \mathrm{L})$ & $1.05-1.21$ & 1.12 \\
\hline \begin{tabular}{c} 
Fluorides $(\mathrm{mg} / \mathrm{L})$ \\
\hline
\end{tabular}
\end{tabular}

\subsection{Oil produced wastewater treatment system}

The schematic diagram of the treatment process was plotted in Figure 1. As shown, the produced water was firstly pretreated by oil separation and gas flotation pond, with the addition of alkali and micro nano bubbles. The sewage after pretreatment discharged into oxidation pond, which integrated aerobic pond and facultative pond. The main design and operation parameters were listed in Table 2.

The constructed wetland system adopted the surface flow constructed wetland technology. The design aera of constructed wetland and ecological construction zone were $1.77 \mathrm{~km}^{2}$ and $10.03 \mathrm{~km}^{2}$, respectively. After further treatment by constructed wetland, the effluent quality could reach the corresponding discharge standard. The purified water could be used as the ecological supplement water for the saline alkali beach wetland in the ecological construction area, and improve the situation of drought and water shortage of plants and salinization.

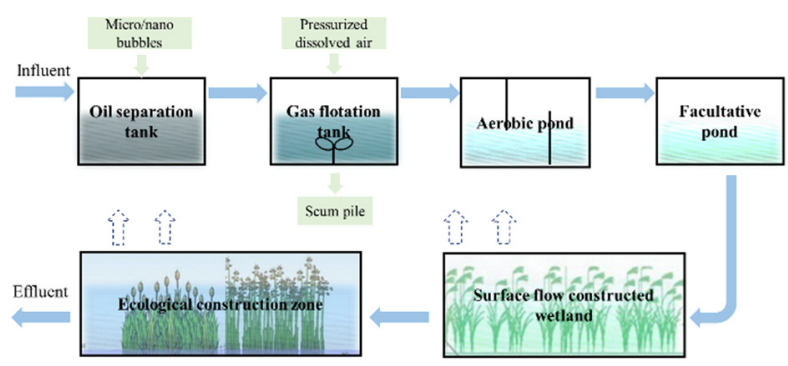

Figure 1. Schematic diagram of the treatment process.

Table2. Parameters of each tank.

\begin{tabular}{cccc}
\hline Type & $\begin{array}{c}\text { Size } \\
\text { (length*width*depth) }\end{array}$ & Volume & HRT \\
\hline $\begin{array}{c}\text { Flocculation } \\
\text { pond }\end{array}$ & $17 \times 17 \times 4$ & 1154 & 1.39 \\
$\begin{array}{c}\text { Aerobic pond } \\
\text { Facultative } \\
\text { pond }\end{array}$ & $136 \times 110 \times 0.5$ & 7480 & 8.98 \\
\hline
\end{tabular}

\subsection{Wastewater quality detection}

The characteristics of the water samples along the whole treatment process were detected. The samples of gas flotation influent (GFI), gas flotation effluent (GFE), aerobic pond effluent (APE), the facultative pond effluent (FPE), the total oxidation pond effluent (OPE), the constructed wetland influent (CWI), the constructed wetland effluent (CWE) and the ecological constructed zone (ECA) were taken during the operation process for water quality analysis. Measurement for water quality parameters of the influent and effluent were in accordance with standard methods. All the water samples were immediately transported on ice to the laboratory and processed.

\section{Results and discussion}

\subsection{Salinity and heavy metal distribution}

Due to the characteristics of high temperature and high pressure with the oil layer environment, the composition of produced water could be very complex. The produced water not only contains crude oil, but also dissolves various suspended solids, salts and heavy metals in the formation[15]. Figure $2 \mathrm{a}$ showed the transfer distributing of salinity and $\mathrm{Cl}^{-}$in the treatment system. The salinity and concentration of $\mathrm{Cl}^{-}$were both high in the influent of flocculation pond, with concentration of $14.4 \mathrm{~g} / \mathrm{L}$ and 8.02 $\mathrm{g} / \mathrm{L}$, respectively. After flocculation pond treatment, the concentration of the above two pollutants both reduced, suggested that air flotation process has removal capacity for both two pollutants to some extent. In the subsequent treatment process, the salinity and $\mathrm{Cl}^{-}$increased continuously, with maximum concentration of salinity was more than $22.1 \mathrm{~g} / \mathrm{L}$ in the effluent of constructed wetland. High salinity increased the difficulty of biochemical treatment. In addition to natural factors such as large evaporation in the constructed wetland, the gradient increase of salinity may result in large part from seawater indraught at the end of wetland.

Figure $2 b$ showed the changes of heavy metals in the influent and effluent. In the whole treatment process, the influent contained less heavy metals, with concentrations of $1.7 \mathrm{mg} / \mathrm{L}$ for $\mathrm{As}, 0.02 \mathrm{mg} / \mathrm{L}$ for $\mathrm{Pb}$ and $0.008 \mathrm{mg} / \mathrm{L}$ for $\mathrm{Ni}$, the concentrations of $\mathrm{Hg}, \mathrm{Cd}$ and $\mathrm{Cr}$ are lower than the detection. These results indicated that not much heavy metals have been produced in the flushing out process by water injection. After treatment process, the contents of heavy metals were further reduced, with concentrations of $\mathrm{As}$ and $\mathrm{Ni}$ reduced to $1.5 \mathrm{mg} / \mathrm{L}$ and $0.006 \mathrm{mg} / \mathrm{L}$, respectively, which had met the corresponding standard.
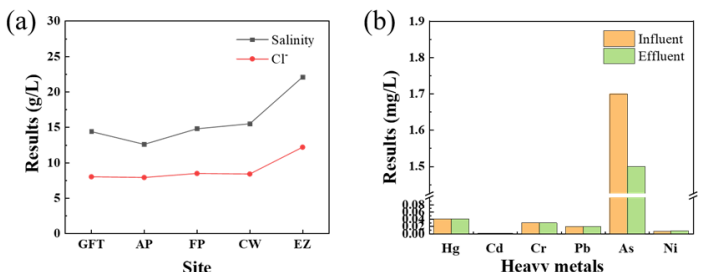

Figure 2. (a)Transfer distributing of salinity and Cl- in the treatment system, (b) Dissipation of heavy metals. 


\subsection{Performance of the oil produced water treatment plant}

Through monitoring the produced wastewater treatment plant for 210 days, the operation performance of produced water treatment plant using combined technology of air flotation and oxidation pond was studied. The changes of $\mathrm{COD}_{\mathrm{Mn}}, \mathrm{NH}_{3}-\mathrm{N}$ and oil in the influent and effluent as well as their removal efficiency are plotted in Figure 3. The gas flotation tank was an unstable operation with large fluctuation of influent quality. The oil of influent ranged from $11 \mathrm{mg} / \mathrm{L}$ to $147 \mathrm{mg} / \mathrm{L}$, and the $\mathrm{COD}_{\mathrm{Mn}}$ fluctuated from $43.9 \mathrm{mg} / \mathrm{L}$ to $71.1 \mathrm{mg} / \mathrm{L}$. Despite that, it performed well as indicated by stable $\mathrm{COD}_{\mathrm{Mn}}$ and oil removal efficiency, averagely $36.3 \%$ and $96.5 \%$, respectively. The average $\mathrm{NH}_{3}-\mathrm{N}$ removal efficiency was $13.7 \%$, and it fluctuated with the water quality(Figure 2e). Figure 2(b) presented $\mathrm{COD}_{\mathrm{Mn}}$ concentration and its removal in the oxidation pond. The removal efficiency (averagely 7\%) was lower than that in the flotation tank. By comparison, the removal efficiency of $\mathrm{NH}_{3}-\mathrm{N}$ increased to $35.9 \%$ averagely, and the concentration of $\mathrm{NH}_{3}-\mathrm{N}$ in the effluent was tending toward stability (Figure 2d). The variation tendency of oil removal was similar to that in flotation tank, with average oil removal efficiencies of $92.1 \%$ (Figure 2f). After biological treatment, the water quality reached: COD $\leqslant 100 \mathrm{mg} / \mathrm{L}$, ammonia nitrogen $\leqslant 15 \mathrm{mg} / \mathrm{L}$, which met the corresponding national standards.

\subsection{Performance of constructed wetland system}

The wastewater treated by the treatment plant entered into the surface flow constructed wetland for further treatment. Through a series of synergistic effect of physical, chemical and biological reactions, the sewage was deeply purified[16].

The characteristics of main pollutants in different locations of constructed wetland and their removal efficiency were presented in Figure 3 and Table 3. It could be seen that all the pollutants were further removed through out the wetland process. At the end of ecological constructed zone, the $\mathrm{COD}_{\mathrm{Mn}}$ and $\mathrm{BOD}_{5}$ were degraded to $26.7 \mathrm{mg} / \mathrm{L}$ and $8.2 \mathrm{mg} / \mathrm{L}$, corresponding to average removal efficiencies of $15.4 \%, 32.8 \%$, respectively. The $\mathrm{BOD}_{5} / \mathrm{COD}$ ratio increased from $0.26 \mathrm{mg} / \mathrm{L}$ of raw water to $0.31 \mathrm{mg} / \mathrm{L}$ of effluent, which indicated that the biodegradability of the wastewater was remarkably enhanced by constructed wetland. The $\mathrm{NH}_{3}-\mathrm{N}$ and $\mathrm{SS}$ were decreased significantly in wetland. After treatment, the $\mathrm{NH}_{3}-\mathrm{N}$ was reduced from $13.8 \pm 0.5 \mathrm{mg} / \mathrm{L}$ to $3.8 \pm 0.8$ $\mathrm{mg} / \mathrm{L}$, representing removal rate of $72.6 \%$, and SS was reduced from $19.5 \pm 1.4 \mathrm{mg} / \mathrm{L}$ to $7.2 \pm 0.7 \mathrm{mg} / \mathrm{L}$, corresponding to the average removal rates of $63.1 \%$. These results indicated that the surface flow constructed wetland shouldered the major part of $\mathrm{NH}_{3}-\mathrm{N}$ removal in the system. Besides, cause the oil was largely removed during the previous treatment process, the influent oil concentration was only $0.2 \pm 0.1 \mathrm{mg} / \mathrm{L}$ while the effluent of that was lower than the detection (Figure 4). After wetland treatment, the effluent could reach: COD $\leq 50$ $\mathrm{mg} / \mathrm{L}$, ammonia nitrogen $\leq 5 \mathrm{mg} / \mathrm{L}$, which satisfied the national discharge standard for water pollutants from the oilfield industry. (a)

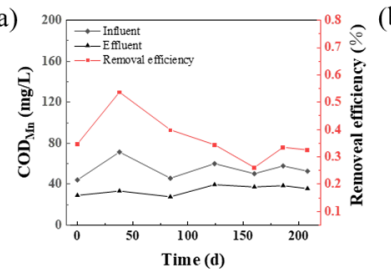

(c)

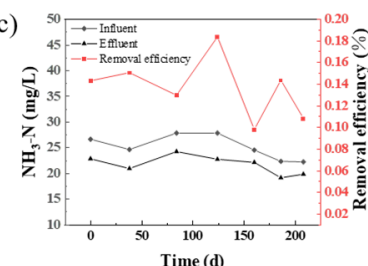

(e)

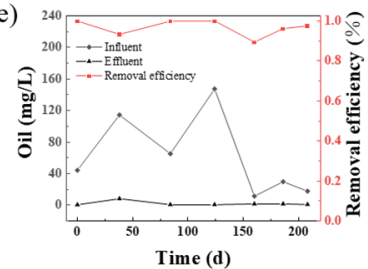

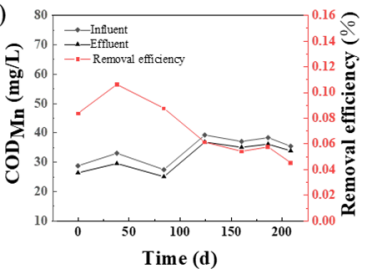

(d)

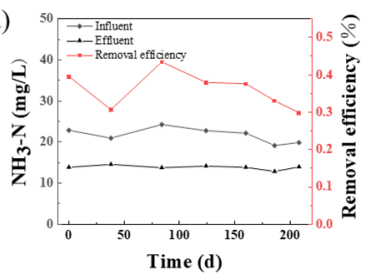

(f)

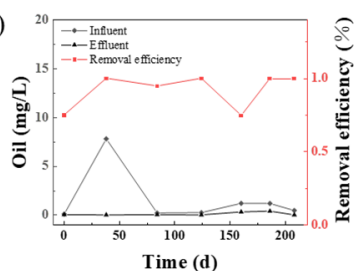

Figure 3. Time course of (a) $\mathrm{COD}_{\mathrm{Mn}}$, (c) $\mathrm{NH}_{3}-\mathrm{N}$, (e) Oil concentration and removal in flotation tank, (b) $\mathrm{COD}_{\mathrm{Mn}},(\mathrm{d})$ $\mathrm{NH}_{3}-\mathrm{N}$, (f) oil concentration and removal in oxidation pond.
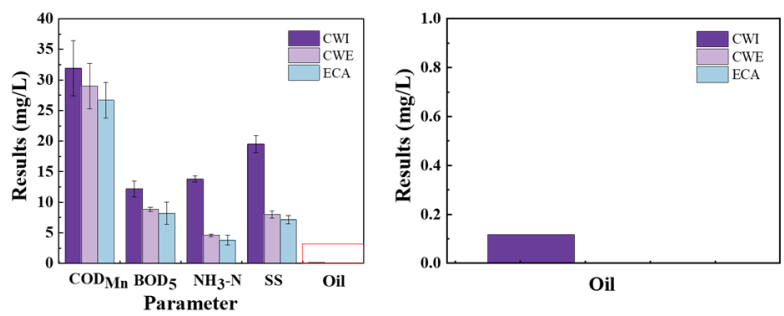

Figure 4. Concentration profiles of $\mathrm{COD}_{\mathrm{Mn}}, \mathrm{BOD}_{5}, \mathrm{NH}_{3}-\mathrm{N}$, SS and oil in constructed wetland system. CWI, constructed wetland influent; CWE, constructed wetland effluent; ECA, ecological constructed aera.

Table3. Characterization of the concentrates of main pollutants of constructed wetland system.

\begin{tabular}{ccccc}
\hline Constituent & $\begin{array}{c}\text { Influent } \\
(\mathbf{m g} / \mathbf{L})\end{array}$ & $\begin{array}{c}\text { Constructed } \\
\text { wetland } \\
(\mathbf{m g} / \mathbf{L})\end{array}$ & $\begin{array}{c}\text { Ecological } \\
\text { constructed zone } \\
(\mathbf{m g} / \mathbf{L})\end{array}$ & $\begin{array}{c}\text { Total } \\
\text { removal } \\
(\%)\end{array}$ \\
\hline $\mathrm{COD}_{M n}$ & $31.9 \pm 4.5$ & $29 \pm 3.7$ & $26.7 \pm 2.9$ & 15.4 \\
$\mathrm{BOD}_{5}$ & $12.2 \pm 1.3$ & $8.8 \pm 0.3$ & $8.2 \pm 1.8$ & 32.8 \\
$\mathrm{BOD}_{5} / \mathrm{COD}$ & 0.38 & 0.3 & 0.31 & - \\
$\mathrm{NH}_{3}-\mathrm{N}$ & $13.8 \pm 0.5$ & $4.6 \pm 0.2$ & $3.8 \pm 0.8$ & 72.6 \\
$\mathrm{SS}$ & $19.5 \pm 1.4$ & $8 \pm 0.6$ & $7.2 \pm 0.7$ & 63.1 \\
$\mathrm{Oil}$ & $0.2 \pm 0.1$ & - & - & - \\
\hline
\end{tabular}




\section{Conclusion}

This study demonstrated that the air flotation and oxidation pond treatment combined with constructed wetland system was an efficient and feasible process for the removal of COD, ammonium nitrogen and oil from the heavy oil produced wastewater. During the stable operation period, the combined process maintained average removal rates of $50.2 \%$ for $\mathrm{COD}_{\mathrm{Mn}}, 100 \%$ for oil and $85.1 \%$ for ammonium nitrogen under the gradient increase of salinity. The biodegradability of the produced water was significantly enhanced by the flotation and oxidation pond treatment, while the surface flow constructed wetland played important roles in both $\mathrm{NH}_{3}$ $\mathrm{N}$ remove and COD oil further degradation. It could be concluded that this treatment system allows efficient treatment of oil produced wastewater with high salinity. The treated water could be used for the saline alkali beach wetland as supplement water, and improved the situation of water shortage and salinization. Therefore, this combined system is feasible for high-salt produced water from oilfield, and has a good promotion prospect.

\section{References}

1. Z. Huang, X. He, C. Nye, D. Bagley, M. Urynowicz, and M. Fan, J. Hazard. Mater. 407, 124348 (2021).

2. M. Lu and X. Wei, Bioresour. Technol. 102, 2555 (2011).

3. M. Jain, A. Majumder, P. S. Ghosal, and A. K. Gupta, J. Environ. Manage. 272, 111057 (2020).

4. A. Fakhru'l-Razi, A. Pendashteh, L. C. Abdullah, D. R. A. Biak, S. S. Madaeni, and Z. Z. Abidin, J. Hazard. Mater. 170, 530 (2009).

5. X. Wang, L. Jiang, Z. Gai, F. Tao, H. Tang, and P. Xu, J. Hazard. Mater. 358, 155 (2018).

6. S. Varjani, A. Pandey, and V. N. Upasani, Sci. Total Environ. 763, 142934 (2021).

7. D. Su, L. Cong, J. Wang, and D. Zhou, Int. J. Environ. Pollut. 38, 69 (2009).

8. G. Ji, T. Sun, Q. Zhou, X. Sui, S. Chang, and P. Li, Ecol. Eng. 18, 459 (2002).

9. G. D. Ji, T. H. Sun, and J. R. Ni, Bioresour. Technol. 98, 436 (2007).

10. J. Vymazal, Ecol. Eng. 73, 724 (2014).

11. M. Jain, A. Majumder, P. S. Ghosal, and A. K. Gupta, J. Environ. Manage. 272, 111057 (2020).

12. W. Liu, M. H. Rahaman, J. Mąkinia, and J. Zhai, Sci. Total Environ. 777, (2021).

13. F. Karray, F. Aloui, M. Jemli, N. Mhiri, S. Loukil, R. Bouhdida, N. Mouha, and S. Sayadi, Process Saf. Environ. Prot. 141, 73 (2020).

14. G. T. Tellez, N. Nirmalakhandan, and J. L. GardeaTorresdey, Environ. Prog. 24, 96 (2005).

15. X. L. Zou, Environ. Technol. (United Kingdom) 36, 2381 (2015).

16. J. Vymazal, Sci. Total Environ. 380, 48 (2007). 